\title{
UK senior doctors' career destinations, job satisfaction, and future intentions: questionnaire survey
}

\author{
Jean M Davidson, Trevor W Lambert, Michael J Goldacre, James Parkhouse
}

Doctors' career choices, destinations, and views about their jobs provide useful insights for workforce planning. We report a survey of all traceable graduates from UK medical schools in 1974.

\section{Participants, methods, and results}

We mailed questionnaires in 1998, asking about employment history and current job. In all, $77 \%$ $(1717 / 2217)$ replied $(72 \%$ (1223) of men and $80 \%$ (494) of women). Of respondents, $97 \%$ (1673) were in medical employment in the United Kingdom or abroad, and $85 \%$ (1460) worked in the UK NHS. The table shows the distribution of their specialties. In NHS general practice, $98 \%(488)$ of men and $85 \%$ (183) of and $5 \%$ (25) of men worked part time. In NHS hospital practice, $97 \%(469 / 485)$ of men and $76 \%(114 / 150)$ of women whose main paid post was in the NHS (not in a university) were consultants; of these, 26\% (30) of women and 11\% (50) of men worked part time.

We asked respondents to score five statements about job satisfaction, from "strongly agree" (score 1) to "strongly disagree" (5). The statements were "I find enjoyment in my current post"; "I am doing interesting and challenging work"; "I feel dissatisfied in my current post"; "most days I am enthusiastic about my work"; "I am often bored with my work"). ${ }^{1}$ We calculated a job satisfaction score by totalling the scores for all five statements: 20 or more represented a positive response, on average, to all statements, and we suggest that this shows a high level of satisfaction.

Respondents rated their job satisfaction reasonably highly (table), with some significant but small differences between occupational groups. Hospital doctors were more satisfied with their jobs than general practitioners; women general practitioners were more satisfied than men (group median scores 19.7 and 18.8 respectively); and part time general practitioners were more satisfied than those working full time (19.8 and 18.9) (all $\mathrm{P}<0.001$ ). This last finding was mainly explained by the comparatively lower job satisfaction of male general practitioners working full time.

Respondents practising medicine in the United Kingdom were asked whether they intended to continue doing so for at least another five years. Most respondents definitely intended to do so; more NHS hospital doctors than general practitioners were definite $(85.8 \%$ (580/ $676)$ and $77.9 \%(553 / 710) ; \mathrm{P}<0.001)$. Reasons cited for considering leaving UK medicine included dissatisfaction or disillusionment with their job or with the NHS; ill health; stress or pressure associated with the job; and a desire for change, travel, other interests, or to work in a developing country.

\section{Comment}

The results provide benchmark findings on the career destinations of doctors who qualified in the 1970 s, with women were principals; of these, $39 \%$ (72) of women which career profiles of more recent generations can be compared. Only a quarter of the 1974 graduates were women. ${ }^{2}$ Women from the 1974 cohort were less likely than men to hold consultant or principal posts, and few women were surgeons. Many more women than men worked part time. In the future NHS, many more of the senior posts will be filled by women because more women than men now enter medical school, ${ }^{3}$ reversing the former situation in which men substantially outnumbered women. As the government recognises, ${ }^{4}$ doctors' working lives need to be balanced with their expectations about raising a family and other interests.

Replies about short term intentions portray a workforce committed to working in the NHS, with stable careers over the next few years. Levels of job satisfaction were generally high. Nevertheless, many respondents commented that they were working close to the limits of what they regarded as a reasonable commitment of their time, and many do not intend to work to the age of $65 .^{5}$

Profile of 1673 respondents (graduates from 1974) in medical employment in 1998: specialty and job satisfaction. Values are numbers (percentages of all medical posts) unless stated otherwise

\begin{tabular}{|c|c|c|c|c|}
\hline Specialty group & Men & Women & Total & $\begin{array}{l}\text { Job satisfaction } \\
\text { score }^{*}\end{array}$ \\
\hline \multicolumn{5}{|l|}{ UK NHS (hospital): } \\
\hline Medical specialties & $136(11.3)$ & $42(9.0)$ & $178(10.6)$ & 20.3 \\
\hline Paediatrics & $26(2.2)$ & $15(3.2)$ & $41(2.5)$ & 20.8 \\
\hline Accident and emergency & $10(0.8)$ & $1(0.2)$ & $11(0.7)$ & 18.8 \\
\hline Surgical specialties & $134(11.1)$ & $12(2.6)$ & $146(8.7)$ & 20.5 \\
\hline Obstetrics and gynaecology & $23(1.9)$ & $7(1.5)$ & $30(1.8)$ & 19.6 \\
\hline Anaesthetics & $70(5.8)$ & $17(3.6)$ & $87(5.2)$ & 19.7 \\
\hline Radiology & $29(2.4)$ & $10(2.1)$ & $39(2.3)$ & 19.7 \\
\hline Clinical oncology & $9(0.7)$ & $8(1.7)$ & $17(1.0)$ & 21.0 \\
\hline Pathology & $40(3.3)$ & $15(3.2)$ & $55(3.3)$ & 19.9 \\
\hline Psychiatry & $44(3.7)$ & $23(4.9)$ & $67(4.0)$ & 19.7 \\
\hline Other medical specialties $†$ & $4(0.3)$ & $5(1.1)$ & $9(0.5)$ & 20.3 \\
\hline All & $525(43.6)$ & $155(33.0)$ & $680(40.6)$ & 20.2 \\
\hline \multicolumn{5}{|l|}{ UK NHS (non-hospital): } \\
\hline General practice & $497(41.3)$ & $216(46.1)$ & $713(42.6)$ & 19.1 \\
\hline Community health & $6(0.5)$ & $44(9.4)$ & $50(3.0)$ & 20.0 \\
\hline Public health medicine & $9(0.7)$ & $8(1.7)$ & $17(1.0)$ & 23.0 \\
\hline All & $512(42.5)$ & $268(57.1)$ & $780(46.6)$ & 19.2 \\
\hline $\begin{array}{l}\text { Total of UK NHS hospital and } \\
\text { non-hospital }\end{array}$ & $1037(86.1)$ & $423(90.2)$ & $1460(87.3)$ & 19.7 \\
\hline \multicolumn{5}{|l|}{ Outside UK NHS: } \\
\hline Other UK public sector & $22(1.8)$ & $5(1.1)$ & $27(1.6)$ & 21.2 \\
\hline UK private medicine & $36(3.0)$ & $10(2.1)$ & $46(2.7)$ & 22.8 \\
\hline Medicine abroad & $109(9.1)$ & $31(6.6)$ & $140(8.4)$ & 21.6 \\
\hline All & $167(13.9)$ & $46(9.8)$ & $213(12.7)$ & 21.8 \\
\hline Total of all medical posts & $1204(100)$ & $469(100)$ & $1673(100)$ & $19.9(100)$ \\
\hline
\end{tabular}

Percentages may not add up exactly owing to rounding.

Results for individual specialties are based on doctors with NHS contracts in the United Kingdom, including 48 men and 7 women whose main paid post was a university post.

*Grouped median score out of a maximum of 25; 1616 doctors (1168 men) gave information about job satisfaction.

†Includes doctors known to be working in medicine but who did not state their specialty.

UK Medical

Careers Research

Group, Unit of

Health-Care

Department of

Public Health,

University of

Oxford, Oxford

Jean M Davidson

research officer

Trevor W Lambert

statistician

Michael J Goldacre

James Parkhouse

Correspondence to: MJ Goldacre michael.goldacre@ dphpc.ox.ac.uk

BMJ 2002;325:685-6 
We thank all the doctors who have participated in the study. Contributors: JP, MJG, and TWL designed the study. Karen Hollick administered the survey, and Janet Justice and Alison Stockford entered the data. JMD analysed the data and wrote the first draft of the paper. All authors contributed to subsequent drafts and approved the final version. JMD, TWL, and MJG will act as guarantors.

Funding: The UK Medical Careers Research Group is funded by the Department of Health. The Unit of Health-Care Epidemiology is funded by the South East regional office of the NHS Executive.

Competing interests: None declared.
1 Lambert TW, Evans J, Goldacre MJ. Recruitment of UK trained doctors into general practice: findings from national cohort studies. Br J Gen Pract 2002;52:364-72

2 Lambert TW, Goldacre MJ, Parkhouse J. Doctors who qualified in the UK between 1974 and 1993: age, gender, nationality, marital status and family formation. Med Educ 1998;32:533-7.

3 UCAS releases first application figures for 2002 entry. (UCAS press release, November 2001.) www.ucas.ac.uk/new/press/press091101.html (accessed 10 July)

4 Department of Health. Improving working lives in the NHS. London: DoH, 1999.

5 Davidson JM, Lambert TW, Parkhouse J, Evans J, Goldacre M. Retirement intentions of doctors who qualified in the United Kingdom in 1974: postal questionnaire survey. J Public Health Med 2001;23:323-8.

(Accepted 20 May 2002)

\section{Commentary: Are contented doctors good doctors?}

$B M J$

Rhona MacDonald

editor of Career Focus

rmacDonald@

bmj.com
Let's make an assumption-that doctors who are satisfied with their careers, can work as much as they want to (full time or part time), and are not overstretched are happy doctors. But do happy doctors make good doctors, and do unhappy doctors make bad doctors? I am not sure.

It is encouraging to see that most of the doctors in this study (who had been qualified for 24 years at the time they responded) were highly satisfied with their jobs. But what about the younger generation of graduates? They have to negotiate many hurdles that their predecessors escaped, such as the ramifications of Calman training (training at the specialist registrar level-introduced in 1996). Are they also satisfied with their careers, and so are happy and therefore good?

The nearest comparison is the BMA cohort study of 545 doctors who graduated in 1995. The seventh annual report, published this year, is interesting, if somewhat depressing. ${ }^{1}$ Twenty one per cent of doctors had changed their choice of specialty in the past year. The main reason for this was "hours of work and working conditions," but in 22\% it was because of the tough competition for specialist registrar posts. It is therefore hardly surprising that a quarter stated that their desire to practise medicine was now "lukewarm" and only $13 \%$ stated that it was very strong (compared with $44 \%$ at graduation). What are we doing wrong?

While Calman training has its good points (standardised and streamlined training in specialty of choice) it is also putting substantial pressure on young doctors. You have to be exceptional rather than competent to gain a "national training number" (entry into the training programme). Even medical students interested in careers in hospital medicine are being advised to do everything they can while they are students so that nothing will be blank on the "desirable criteria" list for specialist training. ${ }^{2}$

As for the unhappiness with the hours of work and working conditions, this is more proof that the "new deal" (introduced in the United Kingdom in June 1991 to reduce junior doctors' working hours to an average maximum of 56 hours a week) has failed miserably. There are even penalty payments for non-compliance and a contractual obligation to comply by target dates. In some cases the new deal has put more pressure on junior doctors, who are sometimes pressurised by the employing trust to lie about their hours of work. ${ }^{3}$ It will be interesting to see if the implementation of the Euro- pean working time directive can do any better. However, some doctors fiercely oppose the implementation of the directive as it will make specialist training even longer-for example, it will now take surgical trainees eight and a half years to accrue the experience currently gained in six years. ${ }^{4}$

Seven per cent of specialist registrars train flexibly, ${ }^{5}$ and while this is a good start, it is not enough, and the scheme is vastly oversubscribed. You also have to have a very good reason for wanting to train flexibly"because I have other interests and want to have a life" is often not good enough.

I don't believe that all this dissatisfaction with careers and working conditions makes today's doctors bad doctors. I think it proves that they have to be very committed to medicine to persist. Surely such dogged commitment is a virtuous and good thing.

On a more positive note, those who regularly read the profiles in Career Focus will know that there are many doctors who still love medicine and are satisfied with their careers. They often have other interests as well, such as writing children's books, being a stand-up comic, and running an art gallery. Could this be the answer to fulfilment, happiness, and therefore "goodness," I wonder?

Competing interests: None declared.

1 Health Policy and Economic Research Unit. BMA cohort study of 1995 medical graduates. Seventh report. London: BMA, 2002.

2 Scoote M, Thaventhiran J, Elkington A. Progress towards higher specialist training. BMJ 2002;325(suppl):S49. www.bmj.com/cgi/content/full/ $325 / 7360 / \mathrm{S} 49 \mathrm{a}$ (Career Focus.)

3 Bryden H. The way I see it: do you trust your hospital trust? BMJ 2002;324(suppl):S175. www.bmj.com/cgi/content/full/324/7349/S175 (Career Focus.)

4 Chesser S, Bownan K, Phillips H. The European working time directive and the training of surgeons. BMJ 2002;325(suppl):S69. www.bmj.com cgi/content/full/325/7362/S69a (Career Focus.)

5 Davies M, Eaton J. Flexible training under the new deal. BMJ 2002;324:1111-2. www.bmj.com/cgi/content/full/324/7346/1111

\section{Endpiece}

Another Osler aphorism

The obstetrician holds the distaff,

The physician spins the thread,

The surgeon cuts it off

Sir William Osler

Submitted by H W Gallagher, retired consultant surgeon, Comber, County Down 